\title{
JUVENTUDE E TRABALHO: ENTRE "FAZER O QUE GOSTA" E "GOSTAR DO QUE FAZ"1
}

\author{
Leila Sollberger Jeolás
}

Docente de Antropologia da Universidade Estadual de Londrina

E-mail: claus@sercomtel.com.br

Maria Elena Melchiades Salvadego de Souza Lima Mestre em Ciências Sociais pela Universidade Estadual de Londrina

E-mail: aldo@sercomtel.com.br

\section{Resumo}

No atual contexto socioeconômico, em que o mundo do trabalho vem sendo palco de grandes transformações, os jovens são afetados diretamente e, de forma profunda, tanto na sua inserção no mercado de trabalho, quanto na maneira de elaborar seus valores e suas expectativas com relação a ele. Partindo do pressuposto de que é através do trabalho que os jovens se inserem na sociedade e que é através dele, dentre outras instâncias sociais que os mesmos constroem sua identidade social, o presente artigo visa analisar as representações sociais sobre o trabalho elaboradas por jovens do ensino médio público de uma escola na cidade de Londrina.

Palavras-chave: representações sociais; juventude; trabalho

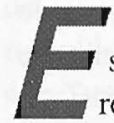

ste artigo foi elaborado a partir dos dados obtidos com a pesquisa realizada para dissertação de mestrado em Ciências Sociais, tendo como objeto de estudo as representações sociais sobre o trabalho elaboradas por jovens de uma escola pública da cidade de Londrina. A

\footnotetext{
' Dissertação defendida no Programa de Pós-Graduação em Ciências Sociais da Universidade Estadual de Londrina, com o título as Representações sociais dos jovens sobre o trabalho: entre o "fazer o que gosta" e "gostar do que faz", sob orientação da Professora Doutora Leila Sollberger Jeolás.
} 
pesquisa objetivava compreender a importância do trabalho em suas vidas e na construção da identidade social, assim como avaliar as suas perspectivas quanto ao futuro no momento de conclusão do último ano do ensino médio.

No atual contexto socioeconômico, no qual o mundo do trabalho vem sendo palco de grandes transformações, considera-se que os jovens são afetados de forma profunda, tanto na sua inserção no mercado de trabalho quanto na maneira de elaborar suas expectativas em relação a ele, principalmente porque é através do trabalho que os jovens pertencentes à classe trabalhadora se inserem na sociedade e adquirem, portanto, condições de construir sua identidade social.

A pesquisa com abordagem qualitativa buscou dar conta dos significados, aspirações, crenças, valores e atitudes dos jovens diante do trabalho, permitindo, ao mesmo tempo, a oportunidade de resgatálos enquanto sujeitos e não apenas como objetos de estudo. O entusiasmo com que os jovens pesquisados se envolveram nas discussões e nas entrevistas desconstrói o estereótipo presente em muitos discursos - de professores, de pais, da mídia e de alguns estudos - de que os jovens são alienados e não se interessam em discutir assuntos como trabalho, escola, família, futuro, dentre outros. Contrariando esses discursos, a maioria se envolveu ativamente no debate, demonstrando grande interesse em dialogar e questionar quando são de fato ouvidos.

A utilização de duas técnicas qualitativas de pesquisa - grupos de discussão e entrevistas individuais aprofundadas - garantiram liberdade de expressão aos jovens em questão ${ }^{2}$ (THIOLLENT, 1982). Ao todo, foram realizadas 16 entrevistas com alunos do terceiro ano do ensino médio, com idade entre 17 e 22 anos (oito do sexo masculino e oito do sexo feminino, sete do período matutino e nove do período noturno), nove das quais estavam trabalhando, cinco já trabalharam, um é pequeno empresário e um nunca trabalhou.

\footnotetext{
${ }^{2}$ As características socioeconômicas da sociedade brasileira que levam os jovens a trabalharem desde muito cedo e, ao mesmo tempo, a defasagem entre idade e série da maioria dos jovens concluintes do ensino médio, levou-nos a considerar a juventude na faixa etária que se estende dos 15 aos 24 anos de idade.
} 
O referencial teórico-metodológico teve como base a antropologia/sociologia dinamista de Balandier (1976a, 1976b, 1997 , 1999), para quem as dinâmicas sociais são processos contínuos e ininterruptos permitindo concluir que o termo "dinâmica" é apresentado como de alcance crítico, contrariando as análises estáticas. Assim, fazse necessário entendermos a sociedade como um processo histórico de produção contínua, demonstrando a possibilidade de analisar tradição e modernidade, ordem e desordem, real e imaginário, de forma que tais pares estejam imbricados, agindo e interagindo uns sobre os outros, possibilitando ainda dizer que as sociedades tomam o aspecto de uma obra coletiva não acabada e sempre a ser refeita.

As representações sociais entendidas como manifestações em palavras, sentidos e condutas que se institucionalizam e expressam a realidade, explicando-a, justificando-a ou mesmo questionando-a (MINAYO, 1994), foram analisadas no seu aspecto dinâmico e de interação com as estruturas e contextos sociais. São expressões de sentido, socialmente elaboradas, que se relacionam sempre à ação, fazendo parte, portanto, de toda prática social. As representações sociais situam-se, dessa forma, na interface do individual e do coletivo e se conformam num processo construtivo, simbólico e criativo em que conteúdos mais estáveis se articulam a outros mais dinâmicos, frutos das transformações sociais.

Para os fins deste artigo, focalizaremos as representações sociais dos jovens sobre o trabalho, apesar deles terem emitido opiniões e preocupações a respeito de outros assuntos como a família e a escola, instituições de referência e por eles valorizadas.

No decorrer dos debates e das entrevistas os jovens fizeram críticas à escola pública atual, questionando sua capacidade de prepará-los para o mercado de trabalho. Criticaram as medidas tomadas pelo governo como o fim dos cursos profissionalizantes, nos quais depositam esperança para conseguirem emprego, não percebendo que os mesmos reforçam a reprodução da divisão de classes e, portanto, das desigualdades sociais. Além disso, criticam as facilidades para passar o aluno para séries subseqüentes com o objetivo de apresentar bons índices estatísticos como a correção de fluxo, a média 5.0, o conselho de classe e a dependência. Para 
eles, isso gera novos fatores responsáveis pela má qualidade da escola pública, bem como pelo desinteresse por parte dos alunos e dos professores.

Quanto à família, esta permanece uma referência e os jovens reconhecem o valor e o incentivo que ela lhes dá para estudarem e trabalharem. Isso os leva a estabelecer com os pais uma relação de reciprocidade na complementação da renda familiar, estando estes últimos constantemente presentes no horizonte de suas preocupações, o que é demonstrado pelo desejo de retribuir, no futuro, o que deles receberam até então. Tal preocupação também está presente em relação aos irmãos.

De volta às representações sociais sobre o trabalho, foco da pesquisa, os jovens manifestaram uma riqueza de opiniões, que gostaríamos de apresentar, pelo menos em parte, nos limites deste artigo. Para a maioria dos participantes dos grupos de discussão e das entrevistas, o trabalho tem papel importante e central em suas vidas, uma vez que lhes garante a sobrevivência e as condições para construção de sua identidade social.

Autores estrangeiros e nacionais demonstram em suas pesquisas a importância do trabalho na vida dos jovens pertencentes à classe trabalhadora. Em se tratando de autores brasileiros, constata-se esta valorização com maior ênfase, pois a realidade da juventude brasileira, no que diz respeito às suas condições sociais, à deficiência da escola pública e à dificuldade em se conseguir um posto de trabalho, tem-se tornado cada vez mais difícil. Estes fatores interferem, certamente, como veremos, na forma como os jovens concebem e valorizam o trabalho atualmente.

Conforme Arias (1998), dados da Pesquisa Nacional por Amostra de Domicílios (PNAD) mostram que no Brasil havia, em 1995, quase 4,5 milhões de desempregados, equivalentes a $6,1 \%$ do total da População Economicamente Ativa (PEA), dos quais 2,1 milhões, ou seja, 47,6\% eram jovens com idade entre 15 e 24 anos. Esses índices agravam-se nas áreas urbanas entre a população de baixa renda e de faixa etária entre 15 e 19 anos. Pochmann (2000) confirma esta tendência ao aumento da taxa de desemprego no Brasil na década de 1990 e chama a atenção para o desemprego da categoria 
jovem, que se elevou em torno de 1,5 vez em relação ao desemprego geral da população, apresentando-se duas vezes maior do que era no final da década de 1980.

A valorização do trabalho é enfatizada de diferentes maneiras pelos jovens: como condição de dignidade para o homem, adquirindo um sentido moral; como instância socializadora, garantindo disciplina, maturidade e responsabilidade; como espaço de sociabilidade e de aquisição de novos conhecimentos; e como garantia de uma margem de autonomia em relação aos pais para assumirem decisões sobre sua vida, sobretudo, quanto à permanência na escola, ao consumo de produtos e marcas juvenis da moda e atividades de lazer - fatores fundamentais para a construção da identidade social do jovem.

Quanto ao primeiro aspecto da valorização do trabalho, os jovens apresentam-no como pressuposto da condição de dignidade. Este aspecto é apontado igualmente por vários autores, a exemplo de Martins (2001) que desenvolveu pesquisas sobre o trabalho com jovens trabalhadores de Osasco. Os jovens sujeitos de sua pesquisa salientaram como mais importante para eles o fato de terem um trabalho. Muitos afirmaram que não gostariam de deixar de trabalhar porque gostam de fazê-lo, porque não conseguem ficar parados e porque o trabalho representa "tudo na vida", pois além de garantir o salário e a sobrevivência, "o trabalho dignifica o homem". Tal realidade se confirma também na pesquisa de Andrade (2000,p.96-97), a qual demonstra o valor do trabalho relacionado à questão ética incorporada no discurso social - "O trabalho dignifica o homem"; "Só através do trabalho é que você pode ser alguém" - e não apenas à questão financeira - "trabalho é dinheiro".

Os jovens, com os quais trabalhamos, reforçaram esta opinião. Estar empregado é muito valorizado por eles, pois garante sua sobrevivência e representa dignidade, significando também autoestima, prestígio e status, contrariando a vergonha e o desprestígio de estarem desempregados. Dentre muitas falas que demonstraram semelhanças entre os jovens participantes desta pesquisa e os sujeitos das pesquisas referidas, destacamos algumas: 
O trabalho é tudo. Sem o trabalho o homem não é nada, não faz. nada. Só se virar marginal. Só que isso não é a forma correta de viver não é!? (masc./18 anos) $)^{3}$

Pra gente que cresceu ouvindo e vendo que o trabalho é necessário, que é importante, não vê outra forma de viver. Eu acho que só trabalhando a gente consegue ganhar a vida, por isso ele é importante.(fem./19 anos)

É como sempre escutei falando, "o trabalho dignifica o homem". Traz dignidade pra pessoa. Eu acho que o trabalho traz muitas coisas positivas, sabe assim. Eu acho que eu mudei totalmente depois que comecei traballhar assim. (masc./17 anos)

Neste sentido, a moral que se inicia na relação familiar é um aspecto presente entre os jovens entrevistados quando se trata da questão trabalho, principalmente quando reconhecem o quanto ele é importante para a sua inserção na sociedade. Nas palavras de alguns alunos: "o cara que não trabalha não tem moral" (masc./17 anos), "...os funcionários que trabalham lá têm a maior moral" (GD), "o desempregado é excluído da sociedade" (GD). Muitos falam dos problemas, dos preconceitos enfrentados pelos desempregados e comentam casos em que o desemprego levou até mesmo ao suicídio. Outro aluno salientou: "o cara quando fica muito tempo desempregado fica tão sem moral que faz besteira mesmo" (masc./18 anos).

Além da importância e da valorização que a família e a escola atribuem aos jovens incluídos no mercado de trabalho, os jovens ressaltam o reconhecimento da sociedade ao jovem trabalhador. Eles deixaram claro que estão conscientes da diferenciação existente na sociedade entre os que trabalham e os que não trabalham, evidenciando os mecanismos rígidos de aceitação social a partir do trabalho. A oposição entre trabalhador e vagabundo faz sentido no processo de auto definição e de identificação dos jovens. Para os que participaram desta pesquisa, o não fazer nada causa vergonha:

\footnotetext{
${ }^{3}$ Utilizou-se sexo e idade para identificar a fala dos alunos que participaram das entrevistas e a sigla GD para identificar os jovens participantes dos grupos de discussão, garantindo assim o anonimato dos mesmos.
} 
Parece que as pessoas fazem uma separação assim sabe, aqueles que trabalham, aqueles que não trabalham. Aí quando você fica no grupo dos que trabalham, você fica diferente. Já os que não trabalham, fica aquela coisa. (GD)

Se você hoje não tem trabalho, você praticamente não é ninguém dentro da sociedade. Então eu acho que o trabalho é importantíssimo na vida de uma pessoa. (masc./18 anos)

Você se apresenta diferente entendeu. Você tá passando na rua. Olha o fulano! Ah o fulano!? Onde ele tava? Tava trabalhando cara. Ô loco!!! Uma hora dessa. É, o cara é um crânio. De repente, você tá ali sentado no cantinho da padaria ou conversando com as meninas né. É o fulano aquele cara ali? É. Nossa! Ele não tá trabalhando?! Não. Já faz seis meses que ele tá sentado naquele cantinho lá. (masc./22 anos)

Este último aluno enfatiza a diferença em estar ou não trabalhando:

Faz. Nossa Senhora! Faz. Uma vez eu fiquei com vergonha porque eu não tava trabalhando e eu moro num condomínio né. E eu tava lá né, sem fazer nada tal. Eu acho que eu tinha até parado de estudar aquele ano. E tô lá eu tal, não sei o que, sempre ficava na portaria, sentadinho na escada conversando com os menininhos. Um dia minha mãe chega em casa e disse que escutou um comentário no ônibus sobre o rapaz que ficava na portaria do prédio sem fazer nada, só conversando com a molecada. Minha mãe me chamou a atenção e me aconselhou para ficar dentro de casa. E eu fiquei porque me senti envergonhado (masc./22 anos).

Esta situação confirma-se no trabalho de Bajoit e Franssen (1997), através dos relatos obtidos de jovens belgas desempregados que revelaram o sentimento de culpa, de vergonha e de desvalorização social. Assim, a afirmação de que "os jovens perderam o sentido do valor trabalho" deve ser repensada, pois o trabalho continua sendo uma importante fonte de normatividade e uma experiência central de socialização. Afirmam os autores:

Trabalhar - quer dizer, exercer uma atividade produtiva com caráter social assegurando uma independência financeira - 
permanece, para todos os jovens que entrevistamos, uma expectativa básica, por vezes essencial, sempre importante. Entretanto, por trás da aparente homogeneidade das expectativas - um trabalho de que se gosta num ambiente positivo, que assegure o reconhecimento social - as experiências vividas e as significações atribuídas ao trabalho são múltiplas. As palavras são as mesmas (trabalho-emprego-desemprego), mas as significações são diversas (p.79).

Embora a sociedade seja constituída de instituições como a família e a escola, além de outras, os jovens referem-se a ela como algo exterior à realidade vivida nestas instituições. Eles parecem não se dar conta de que a família à qual pertencem ou mesmo a escola em que estudam estão presentes na elaboração de seus valores e formam a sociedade que os engloba. Demonstram não perceberem que eles próprios compõem esta sociedade, acreditando que ela, por ser "mais rígida e exigente", é o problema maior enfrentado por eles:

\begin{abstract}
A sociedade é um pouco mais dura né do que a família. A família te aceita não trabalhando. A sociedade já te emplaca, sei lá, como um vagabundo, alguma coisa assim por você não tá trabalhando, sabe. Acho que eles acham que quem não trabalha não é digno.(masc./17 anos)
\end{abstract}

O segundo aspecto da valorização do trabalho pelos jovens passa pela importância do mesmo enquanto instância socializadora, ressaltando a disciplina, a maturidade e a responsabilidade adquiridas através dele. A capacidade de socialização atribuída ao trabalho é apontada pelos jovens quando se referem às normas e à disciplina impostas pelo trabalho, levando-os a respeitarem hierarquias. Tanto na opinião deles quanto na de seus pais, o trabalho representa aquisição de maturidade, marcando uma passagem da socialização realizada até então pela família e pela escola para a socialização realizada no âmbito do trabalho. Assim, é possível concordar com autores como Marques (1997) que vêem o trabalho como um ritual de passagem do mundo infantil para o mundo adulto.

Tal valorização do trabalho contribui para que os jovens trabalhadores tenham uma maior maturidade. Também para Gouveia 
(2000), os jovens pertencentes à classe trabalhadora apresentam elevado nível de maturidade, se comparado aos da classe média, o que os auxilia para que se transformem em "quase adultos" desde cedo. Essa afirmação pode ser observada no discurso dos alunos que participaram dos grupos de discussão e das entrevistas:

[...] acho que amadureci muito depois que comecei trabalhar. Antes eu não dava muito valor pra quem trabalha. Até meus pais eu passei a reconhecer mais pelo esforço que eles fizeram pra sustentar a gente. É, acho que o trabalho deixa a pessoa mais madura, mais reconhecedora das coisas né. (GD)

Sem dúvida, essa maturidade desenvolvida pelos jovens ao ingressarem no mercado de trabalho leva-os a terem uma maior responsabilidade, não só nas funções que passam a desenvolver em seu trabalho, mas também no meio social em que vivem. Logo, a responsabilidade aparece como um aspecto positivo proporcionado pelo trabalho. Eles afirmam que, a partir do momento em que iniciam uma atividade profissional remunerada, tornam-se mais responsáveis com os horários e mais disciplinados, respeitando melhor as regras, dando maior valor ao dinheiro e observando os preços das mercadorias. Além disso, começam a reconhecer o valor da própria família e o incentivo que lhes é dado por estarem trabalhando, demonstrando também a valorização do trabalho pela família e sua influência nesta valorização do jovem. "Eu acho que o trabalho traz mais responsabilidade", disse um jovem e outros assim se manifestaram:

Eu acho que quando você se torna uma pessoa mais madura, você trabalha com mais responsabilidade, você tem confiança da família, você tem uma série de coisas. $\mathrm{O}$ trabalho tanto negativo como positivo, ele te traz muitas coisas. O positivo, assim, mais a confiança da família, a confiança dos amigos, a confiança, sabe, de todos que estão à sua volta. Trabalhando você tem, oh! Tá trabalhando, tá fazendo tal coisa. Você se dedica mais a isso né. Você tem algo a mais a oferecer né. Você tem um direito a mais. (masc./17 anos)

A responsabilidade torna a pessoa mais madura, mais ajuizada. Muda tudo na vida da gente. Até o que se fala em casa. 
Normalmente os pais da gente não falam sobre alguns assuntos, e quando você começa a trabalhar eles mudam e te tratam diferente. (fem./18 anos)

Embora os jovens reconheçam a necessidade de regras de comportamento e de horários a serem cumpridos, aparece com maior ênfase em suas falas a valorização do trabalho. Alguns afirmam que estas regras não os agradam e gostariam de não respeitá-las, assim como gostariam de poder fugir do cansaço, da monotonia e de outros aspectos negativos gerados pelo trabalho.

O terceiro aspecto por eles ressaltado é o do trabalho como espaço de sociabilidade que possibilita o contato com pessoas diferentes e a aquisição de conhecimentos que abrem novos caminhos.

Muitos alunos enfatizaram a importância que o trabalho representa em suas vidas enquanto espaço de sociabilidade, no qual se conhecem novos conteúdos e pessoas: ele "desenvolve um maior conhecimento" (GD), "abre novos horizontes" (fem./22 anos), "é uma forma de distração e de incentivo à vida" (masc./20 anos). Outros assim se manifestaram:

Você cria assim, nossa! Você cresce culturalmente entendeu. Tipo no trabalho onde eu tô ali você conhece tanto o faxineiro quanto o doutor que veio dá palestra lá dos EUA. Você tá no meio de um monte de gente, aprende muita coisa. Vê pessoas ali sofrendo. Você fica naquela assim. O coração já amolece um pouco. Aí você vê um recém-nascido ali saindo de uma cesária. É legal meu, ali é gostoso. Você aprende um pouquinho de cada coisa. (masc./22 anos)

A pessoa que não trabalha, o mundo dela é a casa dela, em torno daquilo. Quando ela sai pra trabalhar sua mente se abre mais, conhece pessoas, tem mais ponto de vista né. O trabalho é uma realização pra pessoa neste sentido. A pessoa passa a ter mais pretensão assim na vida. As idéias são mais claras. Passa a pensar diferente né. (fem./17 anos)

Eles afirmam que o trabalho amplia seu universo social e cultural através da aquisição de novos códigos de laços sociais e relacionamentos com diferentes pessoas, além do acúmulo de 
conhecimentos adquiridos com a experiência que cada ambiente de trabalho proporciona, o que pode, inclusive, favorecê-los na inserção ou permanência no mercado de trabalho, através do "apadrinhamento', ou seja, da indicação por alguém conhecido ou influente.

Segundo eles, o "apadrinhamento" tem sido a melhor forma de arrumar um emprego, principalmente para os jovens que, em razão da sua condição etária, não apresentam experiência e estão terminando seus estudos. Quando perguntado aos alunos se consideravam difícil entrar no mercado de trabalho, as respostas foram bastante diversificadas. Apesar de alguns jovens terem se referido à experiência, ao conhecimento das atividades, à dedicação e à força de vontade em primeiro plano, a questão do "apadrinhamento" esteve presente em grande parte de suas falas:

Eu acho o jeito mais fácil de você conseguir emprego é você conhecendo pessoas, se comunicando, fazendo amizades, pra que aquelas pessoas um dia possam te ajudar né. (masc./18 anos)

Acho que terminando o ensino médio, se você não tiver uma indicação de alguém fica um pouco difícil. Porque geralmente quando você vai pedir trabalho em algum lugar eles pedem experiência ou sempre colocam uma barreira. Então se você não tiver alguém que te indique, fica meio complicado. (masc./17 anos)

Realmente o teste de QI né, como a gente fala, quem indica, está em todo lugar que você vai. (fem./17 anos)

Finalmente, o quarto aspecto valorizado pelos jovens no trabalho refere-se à margem de autonomia que o mesmo propicia para assumirem decisões sobre sua vida. De acordo com Madeira (1986), Bourdieu teria rompido com a visão de que esta busca de autonomia através do trabalho é exclusiva dos setores médios da população, caracterizando-a também entre os jovens operários.

Ainda segundo esta autora, o fato de os jovens da classe trabalhadora serem remunerados permite-lhes o acesso à escola e ao consumo, isto é, à condição de jovens propriamente dita. Não obstante ser o trabalho imprescindível financeiramente para integrarem-se à sociedade, para esta autora, a população jovem, ao inserir-se no mercado 
de trabalho, não o faz movida apenas por necessidade financeira. Há outras razões, como a busca de uma margem de liberdade, mesmo pequena, para tomar algumas decisões sobre suas vidas, principalmente sobre o consumo e sobre a permanência na escola. Conforme suas palavras: "Trabalhar, receber algum salário para quem tem uma 'autonomia apenas relativa' mas está procurando aumentar seu grau de autonomia, só pode significar liberdade" (p.28).

Marques (1997, p.71), citando estudos de autores como Madeira (1986), Gouveia (1982) e Spindell (1995), alega que os mesmos "falam com muita procedência do significado de liberdade na decisão de trabalhar por parte dos jovens" e "ser livre significa ter liberdade para tomar decisões sobre a própria vida; é ter autonomia em fazer uso do seu dinheiro, de comprar, de consumir os bens culturais que os identifiquem como jovens".

Diz Martins (2001, p. 65), o trabalho:

[...] continua sendo central na vida dos indivíduos, mas há a introdução de elementos de liberdade e autonomia, no sentido de buscar a realização das próprias capacidades, reduzir as quantidades e o tempo dedicado ao trabalho, especialmente quando pouco gratificantes e, principalmente, sem o sacrifício da vida afetiva.

Abramo (1994, p.64), por sua vez, ressalta a complexidade do processo de transição para a idade adulta nas sociedades modernas devido à acentuada divisão do trabalho, à especialização econômica e à segregação da família das outras esferas institucionais que produzem rupturas profundas e relações sociais conflituosas; também em razão do aprofundamento das orientações universalistas que provocam uma descontinuidade entre o mundo das crianças e o mundo adulto, implicando um longo tempo de preparação.

Assim, para a autora, a inserção do jovem no mercado de trabalho não define o indivíduo como adulto, mas define, justamente, a condição juvenil, pois possibilita ao jovem viver esta condição. Viver a condição jovem está baseado na possibilidade de aproveitar esse momento de maneira menos comprometida comparativamente ao adulto, vivendo situações de prazer e diversão antes que 
responsabilidades e encargos aumentem com a necessidade de cuidar da família e dos filhos. Em suas palavras:

Nesse caso, a idéia do limite que marca uma inserção social mais adulta parece estar mais fortemente vinculada ao casamento, ou melhor, à constituição de uma nova família, quando então uma série de responsabilidade limitativas se colocam para o indivíduo (ABRAMO,1994, p.64).

Lembramos, entretanto, que essa menor responsabilidade deve ser relativizada, uma vez que o jovem trabalhador brasileiro já assume compromissos na composição da renda familiar, como já apontado neste trabalho.

Para os jovens pesquisados, "ganhar autonomia" ou "ter mais liberdade" em razão do trabalho significa permanência na escola e possibilidade de ter uma margem de negociação em relação ao controle dos pais, principalmente na decisão de reservar parte do salário para o acesso a bens de consumo e atividades de lazer próprios desta faixa etária. Neste sentido, a valorização do caráter provedor do trabalho ganha importância na fala dos jovens, pois lhes permite consumir roupas, CDs e outros produtos e ainda sair nos finais de semana, possibilitandolhes viver a condição jovem e participar do processo de elaboração da identidade juvenil. Vejamos alguns depoimentos:

O jovem tem que trabalhar né, porque senão como ele vai conseguir ter suas coisas, sair com os amigos, viajar, estudar. Nem sempre os pais podem pagar tudo pra ele. Então, se a gente quer ter uma vida legal tem que trabalhar. (fem./19 anos)

Bom, eu trabalho pra ter as minhas coisas. Mesmo tendo que ajudar um pouca a minha família, o que sobra eu gasto com o que eu quero, nem que for pra comprar só uma calça por mês. (fem./ 19 anos)

Eu pretendo juntar dinheiro pra comprar uma moto. Vou fazer 18 anos e tirar a carteira. Acho que isso vai me ajudar muito porque eu vou economizar e ganhar tempo pra ir pro trabalho, pra vir pra escola, além de poder sair no final de semana né. (masc./17 anos) 
Eu preciso continuar trabalhando porque eu sei que não posso contar com minha família, principalmente se eu quiser continuar os estudos depois que eu sair. (GD)

Pode-se constatar a centralidade do trabalho na vida dos jovens entrevistados, o que é reforçado por grande parte dos autores estudiosos do tema, apesar de algumas diferenças menores entre eles.

A centralidade do trabalho está presente em estudos sobre jovens europeus. As pesquisas de Bajoit e Franssen (1997) sobre jovens belgas e de Chiesi e Martinelli (1997) com jovens italianos apontam que a recusa ao trabalho aparece apenas entre uma minoria. Estes estudos, embora obedeçam a especificidades significativas de cada país, buscam traçar o perfil dos jovens europeus da década de 1990. Demonstram semelhanças como o prolongamento da idade juvenil e um novo significado de ser jovem, assim como o crescimento das expectativas de trabalho, principalmente em decorrência do aumento do nível de instrução que os leva a recusar trabalhos que representam pouco prestígio social. Para estes autores, mesmo em contextos culturais diferentes, o trabalho continua sendo um dos meios mais importantes em que se desenvolvem as relações entre as gerações, acentuando os mecanismos de socialização dos jovens para os papéis da vida adulta.

De acordo com Chiesi e Martinelli (1997), em se tratando do caso italiano, o trabalho para os jovens - que por sua vez é atribuído à obtenção de pleno emprego, pois o mesmo é percebido como mais seguro comparado ao passado - perde posição para a família e para as amizades e o amor, primeiro e segundo colocados respectivamente. Sendo assim, permanece em terceira posição, sobressaindo em relação ao tempo livre, ao estudo, à cultura, ao compromisso social, religioso e político. Mas, isto não significa que o trabalho tenha importância somente para aqueles que ainda não se inseriram no mercado de trabalho ou para os que desejam melhorar de emprego. O trabalho é importante também entre aqueles que desenvolvem atividades gratificantes e satisfatórias como os empresários. E a relevância atribuída ao trabalho cresce com o aumento do título de estudo. Constata-se assim não um declínio da importância do trabalho, mas uma transformação de sua concepção. Relatam estes autores: 
O trabalho perde uma posição significativa na competição com outros valores existenciais, mas adquire uma dimensão mais apreciada na aspiração qualitativa. $\mathrm{O}$ trabalho passa a ser cada vez menos uma necessidade cansativa, a ser conquistada, para reduzir os efeitos negativos de sua ausência, mas tampouco passa a ser neutralizado ou circunscrito, uma vez obtido, para reduzir os efeitos negativos de sua presença. (p.123)

Em se tratando da juventude brasileira, devem considerar as diferenças quanto à ênfase dada ao valor do trabalho como central em suas vidas, pois as altas taxas de desemprego, já referidas, e o nível de insegurança proporcionado são fatores que interferem nas suas valorizações e concepções. Segundo Martins (2001, p.65), a situação do trabalhador brasileiro nos anos 1990 contrasta com o quadro do passado "em que o jovem, uma vez alcançado o posto de trabalho, viao como permanente e nele buscava realizar-se e melhorar sua posição", porquanto "a conjuntura atual é de insegurança e de grande mobilidade ocupacional". Sua pesquisa mostra que quase a metade dos jovens $(48,5 \%)$ tem menos de um ano de trabalho, comprovando, assim, a instabilidade em que vivem esses trabalhadores explicando o apego dos mesmos ao trabalho constantemente ameaçado. O desemprego juvenil, sempre superior ao desemprego em geral, constitui uma experiência negativa e traumatizante para a maioria dos jovens, levandoos a valorizarem qualquer tipo de trabalho, mesmo não sendo aquele considerado ideal, como veremos adiante.

A inserção no mercado de trabalho configura-se cada vez mais difícil para os jovens brasileiros em vista dos elevados índices de desemprego, principalmente na faixa etária de 15 a 19 anos (ARIAS, 1998), proporcionando transformações nas suas aspirações, nos modos de vida, nas referências culturais e nos mecanismos de identificações sociais dos jovens. Portanto, pode-se imaginar o grau de insegurança, desesperança e desilusão que isto gera para a juventude brasileira e as conseqüências para o processo de construção das representações sociais sobre o trabalho.

Apesar da importância do trabalho na vida dos jovens, alguns autores questionam a centralidade do trabalho como espaço único para a construção da identidade juvenil. Para Marques (1997), por exemplo, 
existem outras instâncias, além do mundo do trabalho, atuantes neste processo. São elas: a escola, o lazer, o consumo e a religião, que adquirem importância justamente pelo fato de uma maioria dos trabalhadores brasileiros terem, atualmente, uma trajetoria de trabalho regida pela insegurança, instabilidade e precariedade nos vínculos empregatícios. Nas palavras desta autora (p.69): "a dialética do trabalho, embora importante, se não combinada com a dialética de outras relações sociais, torna-se inoperante para explicar o nosso tempo".

Para Martins (1997, 2000), as discussões a respeito do destino do trabalhador levam a acreditar que o trabalho, certamente, não se constitui mais como referência única para o jovem construir sua identidade. Ou seja, para ela, o trabalhador hoje não possui mais segurança de que sua sobrevivência esteja garantida, tampouco "é possível construir sua identidade a partir do trabalho" unicamente.

Em pesquisa sobre os jovens belgas, Bajoit e Franssen (1997) demonstram que as expectativas e as atitudes em relação ao trabalho, ao emprego e ao desemprego continuam a representar uma dimensão privilegiada para apreender a "crise" e a "mutação" das referências culturais entre os jovens nas sociedades industriais atuais. Para eles, mesmo que não seja referência única, o trabalho é ainda marcante para elaboração de identidade dos jovens. Ainda afirmam que as determinações de classe atuam juntamente com valores religiosos e étnico-culturais na configuração de tal identidade. Portanto, o trabalho continua sendo uma importante fonte de normatividade e uma experiência central de socialização, principalmente quando os jovens revelam que o sentimento de culpa e de vergonha assim como de desvalorização social é, muitas vezes, responsável pela perda de identidade social e até da identidade pessoal.

Embora os jovens participantes dos grupos de discussão e das entrevistas tenham enfatizado os valores positivos associados ao trabalho, eles não deixaram de citar aspectos negativos relativos ao mesmo como a rotina, a monotonia, o cansaço, o desgaste, o caráter hierárquico e competitivo das relações de trabalho, o não pagamento dos direitos adquiridos e as dificuldades de obter um emprego com "carteira assinada", como demonstra a fala de um aluno: "mesmo a gente tendo que levantar cedo, trabalhar o dia inteiro, 
chegar aqui na escola super cansado, ainda é melhor ter um emprego do que não ter" (GD).

Entretanto, reconheceram o trabalho como condição necessária da participação social. Não trabalhar coloca em questão a satisfação das necessidades de consumo dos jovens, de lazer, de escolarização/ formação, assim como as expectativas em relação à realização de projetos, ou seja, sua própria inserção social, levando-os a uma atitude pragmática ante a qual qualquer trabalho é melhor do que nenhum:

$\mathrm{Na}$ verdade não tem ponto negativo no trabalho né. Você passa por alguma dificuldade pra colher no futuro. Então eu acho que não tem nada de negativo no trabalho. Trabalho não existe lado negativo né. Ganhando pouco ou muito, você tá ganhando por aquilo que você faz. Então a situação que a gente vive, que o Brasil vive, você tem que se adaptar né. É muito mais fácil você se adaptar ao mundo do que o mundo se adaptar a você. Eu penso assim. Então a gente tem que se adaptar e encarar o jeito que a vida é e bola pra frente, tentar melhorar. (masc./ 18 anos)

Neste sentido, mesmo que o trabalho apresente aspectos negativos - como: o cansaço físico e mental, a determinação do ritmo da vida, a falta de reconhecimento do patrão e de perspectivas quanto ao crescimento profissional, entre outros, - os jovens se vêem obrigados a ter que aceitar o trabalho que aparecer, mesmo sendo uma atividade da qual eles não gostam.

Esse pragmatismo, ou mesmo comodismo de muitos, não impede a manifestação crítica de alguns sobre o "enriquecimento do patrão às custas de seu trabalho", sobre o cumprimento de direitos trabalhistas conquistados e do trabalho alienado, aquele com longas jornadas e imposto pelo ritmo das máquinas e do qual se domina somente parte do processo de produção. Mesmo que suas críticas não dêem conta de explicar a totalidade do processo de exploração do trabalhador, elas demonstram que os jovens percebem, em parte, esta exploração:

Esse negócio do patrão não pagar você em dia é sacanagem. Deveria ter uma lei que protegesse o trabalhador pra que ele ficasse sabendo de seus direitos e pudesse ir atrás deles. (GD) 
A coisa é meio que injusta né. O empregado trabalha, dá o sangue no trabalho, ganha seu salariozinho e quem ganha mesmo é o patrão. Ele é que fica rico, que aproveita a vida. (masc./17 anos)

Eu quero muito trabalhar cara, mas não como o meu irmão que trabalha dia e noite. Eu quero um trabalho que eu possa viver um pouco também né. Nem que for pra ganhar menos do que ele ganha. (masc./18 anos)

Eu saí do meu emprego anterior porque não agüentava mais a pressão do meu patrão. Eu tinha que fazer coisas que não era minha função, como carregar lata de graxa da oficina, pegar peças de caminhão. Eu fui contratada pra trabalhar no escritório, mas eu tava fazendo serviço quase de mecânico. (fem./22 anos)

Carvalho (1994), em pesquisa sobre escola noturna, expõe que, freqüentemente, os alunos entrevistados percebem que, juntamente com o próprio esforço para garantir seu emprego, seu trabalho representa "enriquecimento para o patrão". Apesar disso, há relutância em admitirem servidão, submissão e venda "livre" da força de trabalho, mesmo reconhecendo que vivem num mundo de exploração. Além disso, não manifestam motivação para mudar a realidade e não parecem acreditar que isto seja possível. Exemplifica-se: "bom mesmo é ser político né. Ele dá aumento pra ele mesmo, e aumento muito bom ainda" (GD).

Os jovens têm em mente um trabalho ideal ou o trabalho de seus sonhos: um emprego de seis horas, deixando um pouco de tempo livre para a família, o estudo e o lazer, ou seja, tempo para "vida própria", bem remunerado, valorizado pelo patrão, com garantias ou perspectivas de ascensão e menos monótono. Eles sabem o que desejam:

Bom mesmo é você poder trabalhar num trabalho que você possa usar sua imaginação. Eu gostaria muito de trabalhar numa redação de jornal. Meu sonho é fazer jornalismo né. (masc./17 anos)

Eu gostaria de trabalhar um período e ter um período pra mim. Eu não me importaria de entrar, tipo às 05:00 horas e sair às 13:00 horas do serviço, e ter o resto da tarde pra mim, pra minha casa, pra eu resolver os meus problemas. Antes eu tinha o sábado, agora nem isso. (fem./22 anos) 
Eu gostaria de ter mais tempo para resolver as coisas e pra conversar mais com minha mãe. Ter tempo pra família, também. Igual eu tenho sobrinhos pequenos, às vezes eles exigem muita atenção pra eles. Ah, você não vem mais aqui, não sei o que. Então eu queria ter tempo pra isso. Seria um tempo pra eu cuidar das coisas do jeito que eu gosto, das minhas coisas. (fem./18 anos)

O que eu mais espero agora é encontrar um emprego bom. Que seja registrado na carteira, que tenha vale transporte, vale refeição, férias, $13^{\circ}$ salário, tudo isso aí que é de direito do trabalhador. (fem./17 anos)

Porém, diante da dificuldade em conseguir um emprego e da instabilidade e precariedade dos vínculos empregatícios, os jovens, principalmente aqueles que não pertencem a segmentos de mão-deobra mais qualificada, aceitam, muitas vezes, um trabalho alienante. Afirmam que até os trabalhos mais "sacrificados" podem representar uma oportunidade de experiência necessária para obtenção de melhores empregos, que é o que realmente gostariam de encontrar, mesmo sentindo muitas dúvidas se vão realmente conseguir:

A princípio acho que não tem muito o que escolher né, você acaba sendo escolhido. Você às vezes fala: oh eu sou bom no que eu faço, mas tem muita gente que também tá querendo o emprego e também faz como você. Então não tem muita escolha. (masc.l 17 anos)

Do jeito que as coisas estão, sei lá, acho que não tem muita opção pra gente não sabe. A gente vai ter que pegar o que sobrar. Trabalho melhor mesmo só pra quem já é formado, e olha lá, porque eu conheço gente formada que não consegue emprego também. (GD)

Não adianta esquentar a cabeça não. Até quem tem emprego corre o risco de uma hora pra outra ficar desempregado. O cara pode até ser bom e isso acontece. Meu amigo perdeu o emprego e ele era feroz. (masc./22 anos)

Esse quadro leva a maioria dos jovens a aceitar a falta de reconhecimento por parte do patrão, a submissão (necessária para 
manutenção do emprego segundo eles), os desaforos de clientes e situações desagradáveis do cotidiano no trabalho:

Normalmente o patrão é muito chato. O meu até que não é, mas tem uns aí que a gente fica sabendo que são fogo. O empregado trabalha morrendo de medo dele. Como ele sabe que tem muita gente procurando emprego, ele não quer nem saber dos problemas do empregado. (fem./17 anos)

Eu não gosto quando me tratam mal, que é difícil um dia você sair sem que as pessoas não te tratem mal. Tem meninas ali dentro que já levou até tapa na cara de cliente. E o que vai fazer. O cliente sempre tem razão. (fem./ 18 anos)

A falta de opção leva os jovens a aceitarem as condições que lhes são impostas. Entretanto, falta-lhes transformar as críticas que fazem em ações concretas, através, por exemplo, de uma participação sindical mais efetiva.

Neste contexto de insegurança e incertezas sobre o futuro, provocada, muitas vezes, pelos altos índices de desemprego, a juventude passa por um processo de desilusão que interfere na construção de sua identidade coletiva, acentuando o individualismo provocado pela competitividade.

Segundo Martins (2001, p.81-82), tem sido difundida através de análises sociológicas e dos meios de comunicação de massa "uma imagem do jovem marcada pela negatividade, ressaltando o individualismo, a passividade, a falta de companheirismo e o afastamento das questões que afetam o conjunto dos trabalhadores". Conforme esta autora, as pesquisas de Chiesi e Martinelli (1997) com jovens italianos apontam que apenas $8,2 \%$ dos jovens empregados sob regime contratual tinham participado, nos últimos doze meses, de atividades sindicais, colocando o sindicato em último lugar de interesse. Ainda de acordo com Martins, Chiesi e Martinelli fornecem dados referentes à sindicalização de jovens europeus, comprovando a baixa adesão às entidades sindicais: Itália, 2,1\% dos jovens são sindicalizados; na Espanha, 1,8\%; na França, 2,2\%; e na Alemanha e na Inglaterra $10 \%$. 
Apesar deste fenômeno atingir a todos os trabalhadores, os jovens apresentam o ponto mais crítico dessa crise, o que para esta autora se explica devido à constituição de novos modelos de organização social, de produção, de intervenção política e de valores. Esta realidade vivida pelos jovens europeus em relação ao sindicato apresenta divergências e semelhanças àquela vivida pelos jovens brasileiros.

Baseando-se em seus estudos, Martins (2001) verifica que há uma surpreendente taxa de sindicalização dos jovens entrevistados, especialmente quando comparadas com as taxas européias, apresentando um índice de 48,4\% de sindicalizados contra 51,6\% não sindicalizados. Isso não significa que os mesmos estejam envolvidos com as atividades sindicais, pois somente $19,4 \%$ dos sindicalizados são ativos, enquanto $80,6 \%$ dizem estarem distante do sindicato.

A autora comenta ainda que este comportamento dos jovens brasileiros assemelha-se ao comportamento dos jovens europeus, eles apresentam um certo individualismo, que os impede de construir qualquer identidade com o conjunto dos trabalhadores.

Também com os jovens entrevistados pôde-se perceber uma tendência à individualidade quando se falou em constituição de uma identidade coletiva a partir do trabalho. Segundo a maioria deles, esta individualidade é proporcionada pela concorrência que os impulsiona a serem competitivos na busca por uma vaga no mercado de trabalho, já que não há, segundo muitos deles, nenhuma "instituição" a favor do jovem para facilitar este processo:

Hoje em dia é bem o que dizem mesmo, cada um por si e Deus pra todos. (masc./20 anos)

A gente não pode pensar nos outros não... Então tem que ir em frente e pronto. (fem./22 anos)

Hoje em dia a concorrência é muito grande. Então você tem que pensar em você e pronto. Você tem realmente que mostrar um bom trabalho pra poder segurar o seu lugar. Tem que ter dedicação acima de tudo porque se você não se dedicar tem muita gente querendo o teu lugar. (fem./17 anos)

A população vai aumentando e fica cada vez mais complicado conseguir emprego né. Então os empresários ficam cada vez 
mais exigentes com isso. Por isso pedem experiência, essas coisas, e se torna cada vez mais exigente, porque se não é você tem outra pessoa que pode entrar no seu lugar. (masc./17 anos)

Apesar de tal individualismo que tange o sindicato - muitas vezes influenciado pelas estratégias das empresas para controlarem ou minimizarem a atuação destas entidades sindicais - a pesquisa de Martins (2001, p.84). mostra que " $56,5 \%$ deles, inclusive os não sindicalizados, afirmaram acreditar que a entidade tem uma atuação combativa na defesa dos interesses dos trabalhadores" Tem-se então uma avaliação positiva do sindicato em relação à campanha de filiação e de esclarecimento, sobressaindo como principais funções a luta contra o desemprego, seguida pela luta do não-fechamento de empresas, assim como as tarefas referentes à representação dos interesses econômicos nas relações com governo e empresa, à luta por melhores condições de trabalho e à preocupação com a prestação de serviços (advogados, médicos, dentistas etc.).

O pragmatismo e a atitude de acomodação de parte dos jovens entrevistados explica também algumas afirmações de que o salário é "dado" ou "oferecido" pelo patrão, levando-os a aceitarem o que recebem, por vezes, numa atitude complacente.

O mesmo é observado em outras pesquisas como a de Alves, Rabelo e Souza (1999) sobre o trabalho de mulheres da cidade de Salvador como domésticas, cozinheiras, faxineiras, babás e outras atividades ligadas aos cuidados com a casa e com as crianças, pelo qual recebem baixos salários. Apesar disso, elas reconhecem vantagens que estão ligadas à dinâmica clientelística entre patrão e empregada doméstica como: ganhar roupas e eletrodomésticos usados, indicação de emprego para outros membros da família, ajuda na construção da casa.

Isso explica as opiniões divergentes dos jovens a respeito do valor ideal do salário. Alguns consideram que recebem pouco pelo que fazem e pelo tempo que trabalham, não sendo suficiente para satisfação de suas necessidades, outros afirmam que, embora o salário seja pequeno, consideram-no suficiente pelo serviço que executam.

Dentre os entrevistados, uns disseram que um bom salário estaria em torno de três a quatro salários mínimos, outros, em torno de dez a 
quinze salários mínimos, ficando a média entre cinco e dez salários mínimos. Vale ressaltar que tais valores, inclusive os mais baixos, estão muito distantes do valor do salário que recebem. No entanto, a difícil relação dos jovens com o mercado de trabalho produz insegurança quanto ao futuro, levando-os a considerar que, enquanto não arrumarem um novo emprego com melhor salário, devem continuar no emprego atual e se contentar com o salário que "ganham". A fala de um jovem é exemplar:

\begin{abstract}
Bom, eu posso falar do que eu ganho né. Eu estudo de manhã e trabalho o período da tarde. Trabalho meio período e ganho um salário e mais um pouquinho que o meu patrão me dá a mais. Então eu acho que eu ganho bem pelo que eu faço, pelo tempo que eu trabalho. Trabalho meio período, ganho cento e oitenta reais, não é muita coisa, mas dá pra passar o meu mês ali tranqüilo né. (...) Acho que ganhar bem seria isso. Acho que cobrindo o que você gasta está ótimo né. (masc./18 anos)
\end{abstract}

Diante deste contexto, torna-se complexo falar em trabalho por vocação ou opção por um trabalho que corresponda aos desejos dos jovens trabalhadores que enfrentam as atuais dificuldades do mercado de trabalho. Segundo Willis (1991), os estudos sobre jovens da classe trabalhadora inglesa mostram que eles não têm escolha na hora de buscar um emprego, enquanto os da classe média já estão direcionados aos empregos correspondentes a essa classe. Conquanto seja a classe trabalhadora quem mais sofre atualmente com essa situação, não se pode deixar de considerar que o desemprego é um problema que tem afetado também outras classes. Recorre-se a este autor quando ele afirma que as pessoas vivem seu destino de classe e que o trabalho é um pivô importante desse processo porque é o principal modo de conexão ativo com o mundo. Isto é constatado pelos jovens quando citam exemplos da família, dos amigos e dos conhecidos que perderam o emprego ou correm o risco de perdê-lo, não conseguindo um outro no mesmo padrão e com a mesma remuneração. Demonstra-se, assim, a importância do trabalho ou da inserção do indivíduo no sistema produtivo, pois ele pode mudar o destino desse indivíduo no que diz respeito à classe a que pertence. Prova desse processo se dá quando 
muitos jovens disseram que um dos motivos que levaram suas mães a trabalharem com remuneração foi o pai ter perdido o emprego ou o casal ter-se separado. Até mesmo o ingresso prematuro de alguns jovens no mercado de trabalho se deve a esses motivos:

Eu tô nesse emprego porque não tive a oportunidade de encontrar um outro. Mas eu tô lá porque eu preciso. Se eu sair eu sei que eu vou ficar em casa esperando o emprego chegar até a mim. Eu vou ficar sem dinheiro e isso é uma coisa que é preciso pra sobreviver né. Você tem sua responsabilidade de comprar suas coisas, de pagar suas coisas. (fem./19 anos)

Minha mãe separou do meu pai, desde quando eu tinha três aninhos. Aí, ela cuidou de nós sozinha. Nós somos em cinco irmãs. Então eu comecei a trabalhar cedo. Não tive oportunidade de escolher emprego ou começar a trabalhar mais tarde. Minhas irmãs mais velhas começaram a trabalhar com 10 anos. Eu comecei a trabalhar com 14 anos. Então a gente toda a vida, até minhas irmãs que já estão casadas, elas ajudaram a minha mãe, ajudaram mais né, porque as necessidades eram maiores. (fem./19 anos)

Podemos concluir que, embora tenham em mente um trabalho de seus sonhos, os jovens trabalhadores seguem o que no momento é mais seguro sob o ponto de vista financeiro, por garantia sua sobrevivência e sua condição juvenil.

O "unir o útil ao agradável" e o "fazer o que gosta", mesmo que muitas vezes se transforme em "gostar do que faz", não está ausente do ideal de trabalho dos jovens. Fazer o que gosta e ainda ser bem remunerado financeiramente é o desejo de muitos e está relacionado não somente à questão do emprego, mas também à escolha de uma futura profissão, quando isso lhe for permitido.

Segundo Bock (2000), o jovem pode ser induzido a escolher aquela profissão que seja mais fácil para sua inserção social enquanto cidadão trabalhador, além de buscar uma profissão que lhe dê retorno financeiro mais rápido, mesmo não se identificando com o que vai exercer.

Pode-se concluir que falar em trabalho ideal hoje, portanto, representa, para a maioria dos jovens, o desejo de estar empregado 
ou, pelo menos, trabalhando. Segundo eles, o ideal seria unir o útil ao agradável, ou seja trabalhar naquilo que se gosta. No entanto, se o jovem não pode escolher "fazer o que gosta" ele tem que aprender a "gostar do que faz". São muitas as falas neste sentido:

A situação que o jovem vive hoje faz ele pensar no momento né. Porque às vezes ele tem uma proposta de emprego que nem é o que ele gosta, mas ele aprende a gostar porque retribui financeiramente. É isso o que acontece. Igual no meu caso aí, (...) retribui de uma certa forma pra nossa necessidade. Então mesmo que a gente não goste, tem que fazer. Se não fizer, tem muita gente que quer fazer por menos do que nós. (fem./17 anos)

Eu não gosto do meu trabalho. Eu aprendi a gostar, quer dizer eu aprendi a gostar né. Acostumei né. Hoje em dia, tipo, é fácil mexer com aquilo. Não que eu gosto, não que eu acordo assim, nossa ainda bem que eu voi pegar as minhas ampolinhas, meu soro fisiológico e vou trabalhar, eu não vou com esta sede, mas é gostoso. Eu aprendi muita coisa. (...) Então quando você aprende a fazer é moleza, é gostoso. (masc./22 anos)

Com certeza eu acho que com o tempo você acaba se acostumando com aquilo que você ta fazendo sabe. Acaba até, acho, que se acomodando um pouquinho pelo fato de não conseguir outro emprego que você queria. Então você passa a pensar que você pode continuar neste mesmo e tal. Você passa a ver até as oportunidades que você pode ter no emprego que você tá. (masc./17 anos)

De um lado, pragmatismo e falta de alternativa, de outro, comodismo e aceitação da situação em que vive sem questionamentos, críticas e ações para mudá-la. Embora os jovens façam críticas aos aspectos negativos do trabalho, como vimos, e refiram-se à falta de emprego e excesso de mão-de-obra, à exploração dos patrões e ao caráter alienante do trabalho, eles não conseguem formular uma crítica mais ampla do sistema no qual estão inseridos e, menos ainda, expressar uma possibilidade de reagirem, como sujeitos políticos, a esta realidade, referindo-se a uma identidade coletiva. Alguns parecem interiorizar o discurso do patrão que afirma gerar empregos. Outros têm dificuldade 
de definir um salário ideal, contentando-se em "ganhar" um saláriomínimo. Muitos sentem-se privilegiados quando estão empregados por diferenciarem-se daqueles que estão fora do mercado de trabalho - "Eu vejo tantas pessoas paradas aí que não conseguem arrumar emprego. Então eu me sinto privilegiado". Os jovens parecem acreditar que estão submetidos a uma força maior que foge ao seu controle e, neste processo, o trabalho dos sonhos é substituído pelo sonho de ter um emprego ou, pelo menos, um trabalho. Eles não deixaram de sonhar, fazer projetos para o futuro e criar expectativas de trabalhar naquilo de que gostam, mas, na incerteza de não poder realiza-lo, tentam adaptarse à realidade, aprendendo a "gostar do que fazem". 


\section{Referências}

ABRAMO, Helena Wendel. Mudanças no cenário juvenil. In: Cenas juvenis. São Paulo: Página Aberta, 1994. p.55-74.

ALVES, Paulo César B.; RABELlO, Maria Cristina M.; SOUZA, Iara Maria A. O contexto social da coletânea: o nordeste da Amaralina e seus habitantes. In. (Orgs). Experiência de doença e narrativa. Rio de Janeiro: Fiocruz, 1999.

ANDRADE, Eliane Ribeiro. Juventude, exclusão e educação. Revista Movimento, Rio de Janeiro, n.1, p.88-105, maio 2000.

ARIAS, Alfonso Rodríguez. Avaliando a situação ocupacional e dos rendimentos do trabalho dos jovens. In: COMISSAO NACIONAL DE POPULAÇAO E DESENVOLVIMENTO. Jovens acontecendo na trilha das políticas públicas. 2.ed. Brasília, 1998. v.2.

BAJOIT, Guy; FRANSSEN, Abrahan. O trabalho, busca de sentido. Revista Brasileira de Educação, São Paulo, n.5, p.76-95, 1997.

BALANDIER, Georges. O contorno: poder e modernidade. Rio de Janeiro: Bertran Brasil, 1997.

Antropológicus. São Paulo: Cultrix, 1976a.

As dinâmicas sociais: sentido e poder. São Paulo: Difel, 1976 b.

As encruzilhadas do imaginário. In: O dédalo: para

finalizar o século XX. Rio de Janeiro: Bertrand Brasil, 1999. p.107-187

BOCK, Silvio D. Trabalho: a inserção do jovem no mercado de trabalho. In: ABRAMO, Helena W.; FREITAS, Maria Virginia de; SPOSITO, Marilia Pontes (Orgs). Juventude em debate. São Paulo: Cortez, 2000.

CARVAlHo, Célia Pezzolo de. Ensino noturno: realidade e ilusão. São Paulo: Cortez, 1994.

CHIESI, Antonio; MARTINELLI, Alberto. O trabalho como escola e oportunidade. Revista Brasileira de Educação, São Paulo, n.5, p.111-125, 1997.

GOUVEIA, Patrícia. 'Juyentude-adolescente pobre' e 'valor-trabalho'. In: ALVIM, Rosilene; GOUVEIA, Patrícia (Orgs). Juventude anos 90: conceitos, imagens, contextos. Rio de Janeiro: Contra Capa, 2000. p.59-78..

MADEIRA, Felícia Reicher. Os jovens e as mudanças estruturais na década de 70: questionando pressupostos e sugerindo pistas. Cadernos de pesquisa, São Paulo, n.58, p.15-48, ago. 1986. 
MARQUES, Maria Ornélia da S. Escola noturna e jovens. Revista Brasileira de Educação, São Paulo, n.5, p.63-75, 1997.

MARTINS, Heloisa Helena Teixeira de Souza. O Jovem no mercado de trabalho. Revista Brasileira de Educação, São Paulo, n.5, p.97-108, 1997.

A juventude no contexto da reestruturação produtiva. In: ABRAMO, Helena W.; FREITAS, Maria Virginia de; SPOSITO, Marília Pontes (Orgs). Juventude em debate. São Paulo: Cortez, 2000.

O processo de reestruturação produtiva e o jovem trabalhador: conhecimento e participação. Tempo Social; Rev. Sociol. USP, São Paulo, ano 13, n.2, p.61-87, nov. 2001.

MINAYO, Maria Cecília de S. O conceito de representações sociais dentro da sociologia clássica. In: JOVCHELOVITCH, Sandra; GUARESCHI, Pedrinho (Orgs). Textos em representações sociais. Petrópolis: Vozes, 1994. p.89-110.

POSHMANN, Marcio. Emprego e desemprego juvenil no Brasil: as transformações nos anos 90. Revista Movimento, Rio de Janeiro, n.1, p.73-87, maio 2000 .

THIOLLENT, Michel J. M. Crítica metodológica, investigação social e enquete operária. 3.ed. São Paulo: Polis, 1982.

WILLIS, Paul. Aprendendo a ser trabalhador: escola, resistência e reprodução social. Porto Alegre : Artes Médicas, 1991.

\section{Abstract}

In the current social-economic, in that the world of the work is being stage of great transformations, the youths are directly affected and, in a deep way, so much in your insert in the job market, as in the way to elaborate your values and your expectations with relationship to him. Leaving of the presupposition that is through the work that the youths interfere in the society and that it is through him, among other social instances that the same ones build your social identity, to present research it seeks analyze the social representations on the work elaborated by youths of the teaching medium public of a school in the of Londrina.

Key Words: social representations; youth; work 